\title{
IMPLEMENTASI MEDIA TIGA DIMENSI KEMAGNETAN BERBASIS INKUIRI MELALUI STRATEGI KOOPERATIF TERHADAP SIKAP ILMIAH SISWA
}

\author{
Ahmad Harjono $^{1}$, A. Wahab Jufri' ${ }^{2}$, Kurniawan Arizona ${ }^{1}$ \\ 1) Program Studi Pendidikan Fisika FKIP \\ 2) Program Studi Pendidikan Biologi FKIP \\ Universitas Mataram \\ Mataram, Indonesia \\ Email : ahmad_hardjono@yahoo.com
}

\begin{abstract}
The aim of this study was to determine the influence of the integrated MTDKBI through cooperative strategies for students'scientific attitude. The study used quasi-experiment method with a $2 \times 2$ factorial design research. The population was 380 students of grade 9 SMPN 10 Mataram whose spread.at 10 classes. The sample was 142 students divided into 4 classes with cluster random sampling technique. The research instruments such as questionnaires of scientific attitude which was given at the beginning and the end of the study. The data were analyzed with two-way Ancova. The results showed that (1) the students who learned using MTDKBI significantly different at the aspect of scientific attitude than students who learned with non MTDKBI, (2) students who learn through STAD cooperative strategy significantly different at the aspect of scientific attitude than students who learn with NHT type, (3) there is an interaction effect between the type of media with cooperative strategies for students' scientific attitude.
\end{abstract}

Keywords : MTDKBI, STAD, NHT, Scientific attitude

\section{PENDAHULUAN}

Siswa diharapkan memiliki kemampuan inkuiri ilmiah untuk menumbuhkan kemampuan berpikir dan bersikap ilmiah. Namun implementasi pembelajaran IPA Fisika masih dilandasi oleh pembelajaran berpusat pada guru. Peran guru lebih banyak sebagai sumber informasi yang mentransformasikan pengetahuan yang dimiliki kepada siswa. Guru mentransfer pengetahuannya sebanyak mungkin dan jarang mengajak siswa melakukan inkuiri ilmiah. Salah satu faktor penyebabnya yaitu sarana pembelajaran seperti media dan alat praktikum yang belum memadai, sehingga secara tidak langsung berimplikasi terhadap sikap ilmiah siswa yang belum terbina dengan baik.

Pembelajaran Fisika khususnya materi "kemagnetan" bersifat abstrak. Teori dan hipotesis sebaiknya tidak diberikan secara dogmatis, dengan demikian pelaksanaan pembelajaran tidak hanya menghafal. Keterlibatan siswa secara aktif melalui berbagai kegiatan sains sangat diperlukan [1]. Penggunaan media pun guru lebih cenderung mendominasi, hanya beberapa siswa yang ikut terlibat dalam penggunaan media. Berdasarkan fenomena ini perlu ada suatu upaya agar media pembelajaran dapat dipraktekkan langsung oleh siswa baik secara individu maupun kelompok.
Penggunaan media tiga dimensi kemagnetan (MTDK) berbasis inkuiri (BI) memberikan peluang kepada siswa untuk mengkonstruksi pengetahuannya dan membangun konsep siswa. Hal tersebut dapat membantu siswa memahami sifat kemagnetan secara mendalam. Walaupun media yang digunakan sederhana, namun diharapkan dapat membantu siswa memahami magnet lebih baik, sehingga meningkatkan proses pembelajaran. Keterlibatan siswa secara aktif dalam proses inkuiri ilmiah merupakan tuntunan dasar dalam pelajaran Fisika. Kegiatan inkuiri ilmiah mampu menanamkan dan membudayakan kebiasaan berpikir dan berperilaku ilmiah yang kritis, kreatif dan mandiri, sehingga berdampak pada peran guru yang bergeser menjadi fasilitator yang lebih memfokuskan pada aktivitas siswa. Dalam hal ini, siswa dilibatkan aktif memecahkan masalah untuk menemukan solusi.

MTDKBI diintegrasikan dengan strategi kooperatif sehingga mendukung pembelajaran PAIKEM (aktif, inovatif, kreatif, efektif, dan menyenangkan). Strategi kooperatif akan mereduksi permasalahan pembelajaran yang bersifat klasikal dengan jumlah siswa yang banyak. Para siswa yang tergabung dalam satu kelompok akan saling membantu. Siswa kurang pandai dapat belajar dalam suasana menyenangkan karena banyak temannya yang membantu dan memotivasinya. Siswa yang sebelumnya terbiasa bersikap pasif setelah menggunakan pembelajaran 
kooperatif akan beradaptasi berpartisipasi aktif agar bisa diterima oleh kelompoknya [2].

Upaya peningkatan kemampuan siswa tidak hanya dalam aspek kognitif, tetapi juga faktor penunjang sikap ilmiah. Pengintegrasian MTDKBI melalui strategi kooperatif diharapkan dapat meningkatkan sikap ilmiah siswa sebagai bekal pengembangan kecakapan hidup di masa depan. Membiasakan siswa aktif memecahkan masalah merupakan bekal bagi siswa untuk memiliki kompetensi yang dapat memecahkan masalah dalam kehidupan sehari-hari. Berdasarkan paparan tersebut, tujuan penelitian ini yaitu untuk mengetahui pengaruh jenis media, tipe strategi kooperatif, dan pengaruh interaksi antara keduanya terhadap sikap ilmiah siswa.

\section{Tinjauan Pustaka}

\section{A. Media Tiga Dimensi Kemagnetan}

Istilah media berasal dari bahasa Latin, merupakan bentuk jamak dari "medium" yang secara harfiah berarti perantara atau pengantar. Makna umumnya adalah segala sesuatu yang dapat menyalurkan informasi dari sumber kepada penerima informasi. Proses belajar mengajar pada dasarnya juga merupakan proses komunikasi, sehingga media yang digunakan dalam pembelajaran disebut media pembelajaran [3].

Jenis media yang biasa digunakan dalam kegiatan pendidikan dan pengajaran di antaranya media dua dimensi, media tiga dimensi, media proyeksi, media audio, dan lingkungan sebagai media pembelajaran [4]. Media tiga dimensi merupakan sekelompok media tanpa proyeksi yang penyajiannya secara visual tiga dimensional. Kelompok media ini dapat berwujud sebagai benda asli baik hidup maupun mati dan dapat pula berwujud sebagai tiruan yang mewakili aslinya [5].

Moedjiono (1992) mengatakan bahwa media sederhana tiga dimensi memiliki kelebihan-kelebihan yaitu: a) memberikan pengalaman secara langsung, penyajian secara konkret dan menghindari verbalisme, b) dapat menunjukkan objek secara utuh baik konstruksi maupun cara kerjanya, c) dapat diperlihatkan struktur organisasi secara jelas, d) dapat mewujudkan alur suatu proses secara jelas. Kelemahan media tiga dimensi yaitu tidak bisa menjangkau sasaran dalam jumlah yang besar, penyimpanannya memerlukan ruang yang besar dan perawatannya yang rumit [5].

\section{B. Pembelajaran Berbasis Inkuiri}

Pembelajaran berbasis inkuiri merupakan pembelajaran konstruktivis yang dapat mengoptimalkan penggunaan MTDK untuk meningkatakan pemahaman dan sikap ilmiah siswa.
Pembelajaran inkuiri merupakan suatu pendekatan di dalam mempelajari dan memahami alam sekitar melalui serangkaian kegiatan meliputi merumuskan pertanyaan, melakukan investigasi, observasi, dan menjelaskan hasilnya [6]. National Science Education Standard (NSES) menjelaskan inkuiri dalam pendidikan dapat memfasilitasi peserta didik untuk belajar melalui kegiatan beraneka segi yang mengikutsertakan kegiatan observasi; membuat pertanyaan; memeriksa buku dan sumber lain dari informasi untuk melihat apa yang telah diketahui sebelumnya; merencanakan investigasi; memeriksa ulang apa yang telah diketahui di pandang dari sudut kegiatan eksperimen; menggunakan alat untuk mengumpulkan data; menganalisis dan menginterpretasikan data, mengajukan jawaban, menjelaskan dan memprediksi, serta mengkomunikasikan hasil [7].

Proses inkuiri menuntut guru bertindak sebagai fasilitator, narasumber dan penyuluh kelompok. Para siswa didorong untuk mencari pengetahuan sendiri, bukan dijejali dengan pengetahuan. Pembelajaran inkuiri dapat berhasil bila guru memperhatikan kriteria sebagai berikut: a) mendefinisikan secara jelas topik inkuiri yang dianggap bermanfaat bagi siswa, b) membentuk kelompok-kelompok dengan memperhatikan keseimbangan aspek akademik dan aspek sosial, c) menjelaskan tugas dan menyediakan balikan kepada kelompok dengan cara yang responsif dan tepat waktu, d) intervensi untuk meyakinkan terjadinya interaksi antara pribadi secara sehat dan terdapat dalam kemajuan pelaksanaan tugas, dan e) melakukan evaluasi dengan berbagai cara untuk menilai kemajuan kelompok dan hasil yang dicapai [8].

Pembelajaran berbasis inkuiri dalam penelitian ini diadaptasi dari berbagai refrensi [6] [9] [10] yang dituangkan dalam lembar hasil inkuiri kemagnetan siswa (LHIKS) dengan tahapan sebagai berikut:

\section{Mengajukan Pertanyaan dan Permasalahan}

Pada tahap ini, guru memberikan pertanyaan pengarah pada siswa melalui LHIKS, sebagai bekal siswa dalam merumuskan hipotesis.

\section{Merumuskan Hipotesis}

Setelah masalah berhasil distrukturkan oleh siswa, siswa diharapkan dapat mengajukan hipotesis untuk menjelaskan ide ataupun gagasan mereka yang dituangkan dalam LHIKS.

\section{Mengumpulkan Data}

Pada tahap ini siswa melaksanakan eksperimen untuk menguji hipotesis yang telah dirumuskannya. Hipotesis digunakan untuk menuntun proses pengumpulan data. Siswa dibagi dalam beberapa 
kelompok kecil dan mereka menetapkan cara melaksanakan eksperimen untuk menguji hipotesisnya, sedangkan guru hanya menyediakan sarana seperti LHIKS, MTDK, lembar panduan inkuiri kemagnetan siswa (PIKS) dan sebagainya yang diperlukan siswa dalam eksperimen. Setelah itu siswa mengumpulkan data yang diperlukannya. Data yang dihasilkan dapat berupa data mentah, tabel, dan grafik.

\section{Analisis Data}

Siswa bertanggung jawab menguji hipotesis yang telah dirumuskan dengan menganalisis data yang telah diperoleh, baik data kualitatif maupun kuantitatif. Faktor penting dalam menguji hipotesis adalah pemikiran benar atau salah. Setelah memperoleh kesimpulan dari data percobaan, siswa dapat menguji hipotesis yang telah dirumuskan. Apabila hipotesis itu salah atau ditolak, siswa dapat menjelaskan sesuai dengan proses inkuiri yang telah dilakukannya.

\section{Membuat Kesimpulan}

Langkah penutup dari pembelajaran inkuiri adalah membuat kesimpulan berdasarkan data yang diperoleh siswa yang ditulis pada LHIKS.

\section{Strategi Pembelajaran Kooperatif}

Implementasi MTDKBI dalam pembelajaran di kelas diintegrasikan dengan strategi kooperatif. Pembelajaran kooperatif merupakan bentuk pembelajaran dengan cara siswa belajar dan bekerja dalam kelompok-kelompok kecil secara kolaboratif yang anggotanya terdiri dari empat sampai enam orang dengan struktur kelompok bersifat heterogen. Pembelajaran kooperatif merupakan model pembelajaran yang paling sering digunakan dan sangat dianjurkan oleh para ahli pendidikan [11].

Pembelajaran kooperatif dicirikan oleh struktur tugas (cara pembelajaran dan jenis kegiatan siswa), tujuan (tingkat ketergantungan siswa untuk menyelesaikan tugas), dan penghargaan (reward) kooperatif. Siswa yang bekerja dalam situasi pembelajaran kooperatif didorong untuk bekerjasama dan mereka harus mengkoordinasikan usahanya untuk menyelesaikan tugasnya. Dalam penerapan pembelajaran kooperatif, dua atau lebih individu saling tergantung satu sama lain untuk mencapai satu penghargaan bersama. Mereka akan berbagi penghargaan tersebut seandainya mereka berhasil sebagai kelompok terbaik [12].

Hasil penelitian yang menunjukkan manfaat pembelajaran kooperatif bagi siswa dengan hasil belajar rendah menurut Ludgren (1994); Nur et al. (1987) sebagai berikut: a) meningkatkan pencurahan waktu pada tugas, b) rasa harga diri menjadi lebih tinggi, c) memperbaiki kehadiran, d) penerimaan terhadap perbedaan individu menjadi lebih besar, e) perilaku mengganggu menjadi lebih kecil, f) konflik antar pribadi berkurang, g) sikap apatis berkurang, h) motivasi lebih besar atau meningkat, i) hasil belajar lebih tinggi, dan j) meningkatkan kebaikan budi, kepekaan, dan toleransi [13].

Berdasarkan keunggulan dan manfaat pembelajaran kooperatif di atas, penggunaan MTDKBI akan lebih tepat diterapkan dengan menggunakan strategi kooperatif.

\section{Strategi kooperatif tipe STAD}

STAD dikembangkan oleh Robert Slavin dan teman-temannya di Universitas John Hopkin. STAD merupakan pembelajaran kooperatif yang paling sederhana [13]. Tipe STAD adalah salah satu strategi kooperatif yang banyak diteliti di berbagai ranah pelajaran termasuk IPA. Strategi tipe STAD siswa dibagi menjadi kelompok-kelompok [11]. Jumlah anggota dalam satu kelompok 4-5 orang yang harus heterogen, terdiri dari laki-laki dan perempuan, memiliki kemampuan tinggi, sedang dan rendah. Berikut sintaks dari strategi kooperatif tipe STAD [14].

Anggota tim menggunakan lembar kegiatan dan perangkat pembelajaran yang lain untuk menuntaskan materi pelajarannya dan kemudian saling membantu satu sama lain untuk memahami bahan pembelajaran tersebut. Pada akhirnya nanti siswa menjalani kuis perorangan tentang materi tersebut, dan pada saat itu mereka tidak boleh saling membantu satu sama lain. Nilai-nilai hasil kuis siswa diperbandingkan dengan nilai rata-rata mereka sendiri yang diperoleh dari sebelumnya dan nilai-nilai itu diberi hadiah berdasarkan pada seberapa tinggi peningkatan yang bisa mereka capai. Nilai-nilai ini kemudian dijumlah untuk mendapat nilai kelompok, dan kelompok yang dapat mencapai kriteria tertentu bisa mendapatkan hadiah atau sertifikat [11].

Tabel 1. Sintaks Strategi Kooperatif Tipe STAD

\begin{tabular}{ll}
\hline Sintaks & Kegiatan \\
\hline Pembagian Kelompok & $\begin{array}{l}\text { Guru membentuk beberapa kelompok yang terdiri dari 4 atau 5 siswa yang } \\
\text { heterogen dari segi jenis kelamin, etnis, dan kemampuan akademik. }\end{array}$ \\
Presentasi Guru & $\begin{array}{l}\text { Guru menyampaikan materi pelajaran. Di dalam proses pembelajaran guru } \\
\text { dibantu oleh media, demonstrasi, dan lain-lain. Dijelaskan juga tentang }\end{array}$ \\
\hline
\end{tabular}




\begin{tabular}{ll}
\hline Sintaks & Kegiatan \\
\hline & keterampilan dan kemampuan yang diharapkan dikuasai oleh siswa. \\
& $\begin{array}{l}\text { Guru menyiapkan lembaran kerja sebagai pedoman, sehingga semua } \\
\text { anggota menguasai dan masing-masing memberi kontribusi. Selama tim } \\
\text { bekerja guru melakuakan pengamatan, memberi dorongan, membimbing } \\
\text { dan memberi bantuan jika diperlukan. }\end{array}$ \\
& $\begin{array}{l}\text { Guru memberikan tes/kuis kepada setiap siswa secara individu dan tidak } \\
\text { dibenarkan bekerjasama. Hal ini dilakuakan untuk menjamin agar siswa } \\
\text { secara individu bertanggung jawab kepada diri sendiri dan memahami } \\
\text { bahan ajar. } \\
\text { Pelaksanaan Kuis (Evaluasi) } \\
\text { Setiap siswa diberikan skor dasar dari skor kuis sebelumnya atau skor yang } \\
\text { sudah dimiliki siswa. Hal ini bertujuan untuk memancing motivasi siswa } \\
\text { agar belajar lebih baik dari sebelumnya. } \\
\text { Guru dapat memberi penghargaan berupa sertifikat atau bentuk } \\
\text { penghargaan lainnya kepada kelompok siswa yang berhasil mencapai } \\
\text { kriteria yang sudah ditentukan oleh guru. }\end{array}$ \\
\hline
\end{tabular}

(Sumber: Rusman, 2010)

\section{Strategi kooperatif tipe NHT}

Number Head Together (NHT) merupakan suatu pendekatan yang dikembangkan oleh Spencer Kagan untuk melibatkan siswa dalam menelaah materi yang tercakup dalam suatu pelajaran dan mengecek pemahaman mereka terhadap isi pelajaran dengan guru mengajukan pertanyaan kepada seluruh kelas [12]. Guru menggunakan struktur empat langkah sebagai berikut:

Tabel.2. Sintaks Strategi Kooperatif tipe NHT

\begin{tabular}{ll}
\hline Sintaks & Kegiatan \\
\hline Penomoran & $\begin{array}{l}\text { Guru membagi siswa ke dalam kelompok beranggotakan 3-5 orang dan } \\
\text { kepada setiap anggota kelompok diberi nomor antara 1 sampai 5 }\end{array}$ \\
$\begin{array}{l}\text { Mengajukan pertanyaan atau } \\
\text { tugas }\end{array}$ & $\begin{array}{l}\text { Guru mengajukan sebuah pertanyaan atau tugas kepada siswa. Pertanyaan } \\
\text { dan tugas dituangkan dalam bentuk lembar kerja siswa. }\end{array}$ \\
Berpikir Bersama & $\begin{array}{l}\text { Siswa menyatukan pendapatnya terhadap jawaban pertanyaan itu dan } \\
\text { meyakinkan tiap anggota dalam timnya mengetahui jawaban itu. }\end{array}$ \\
Menjawab & $\begin{array}{l}\text { Guru memngil suatu nomor tertentu, kemudian siswa yang nomornya } \\
\text { dipanggil mengacungkan tangannya dan mencoba untuk menjawab } \\
\text { pertanyaan untuk seluruh kelas. }\end{array}$ \\
\hline
\end{tabular}

\section{Sikap Ilmiah}

Sikap ilmiah yaitu sikap ingin tahu tentang benda, fenomena alam, makhluk hidup, serta hubungan sebab akibat yang menimbulkan masalah baru yang dapat dipecahkan melalui prosedur yang benar. Sikap ilmiah merupakan salah satu unsur yang ada di hakikat IPA [16]. Sikap ilmiah sebagai hasil belajar sangatlah penting bagi siswa karena dapat meningkatkan daya kritis siswa terhadap fenomena alam yang dihadapi, sehingga tidak apriori terhadap fenomena alam yang terjadi. Siswa senantiasa dihadapkan pada fenomena-fenomena alam dalam kesehariannya, sehingga dalam menyikapi permasalahan tersebut tidak hanya mengandalkan

(Sumber: Ibrahim et al., 2000; Arends, 2008)

penguasaan teoritis saja tetapi harus disertai dengan sikap ilmiah yang menjadi tolak ukur tingkat pemahaman yang dimiliki oleh siswa [16].

Indikator sikap ilmiah pada kelas IX pada jenjang sekolah menengah diarahkan untuk mengacu pada Project 2061 NSES yaitu curiosity (keingintahuan), honesty (kejujuran), openness (keterbukaan), dan skepticism (skeptis) [17]. Sementara yang ditetapkan BSNP tentang Standar Isi untuk satuan pendidikan dasar dan menengah, menjelaskan bahwa mata pelajaran IPA bertujuan agar siswa memiliki kemampuan dalam memupuk sikap ilmiah yaitu jujur, objektif, teliti, terbuka, tanggung jawab, disiplin, dan dapat bekerjasama dengan orang lain [18]. Menurut 
Brotowidjoyo, orang yang berjiwa ilmiah adalah orang yang memiliki 7 sikap ilmiah: sikap ingin tahu, sikap kritis, sikap terbuka, sikap objektif, sikap rela menghargai karya orang lain, sikap berani mempertahankan kebenaran, dan sikap menjangkau ke depan [19]. Indikator sikap ilmiah yang akan diteliti yaitu: keingintahuan, kejujuran, keterbukaan, skeptis, objektivitas, kedisiplinan, tanggung jawab, keberanian dalam kebenaran, berpikir ke depan dan ketelitian.

\section{Metode Penelitian}

Penelitian ini dikategorikan sebagai penelitian eksperimen semu (quasi experiment) dengan desain faktorial 2x2 yang dilaksanakan dengan rancangan kelas acak. Jenis media sebagai faktor pertama memiliki dua dimensi yaitu MTDKBI dan nonMTDKBI. Faktor kedua adalah strategi kooperatif yaitu tipe STAD dan NHT. Pelaksanaan penelitian pada dimensi faktor pertama dikombinasikan dengan faktor kedua, sehingga terdapat empat kombinasi perlakuan, yaitu a) kombinasi MTDKBI dengan strategi kooperatif tipe STAD, b) kombinasi MTDKBI dengan strategi kooperatif tipe NHT, c) kombinasi nonMTDKBI dengan strategi kooperatif tipe STAD, dan d) kombinasi nonMTDKBI dengan strategi kooperatif tipe NHT.

Berdasarkan rancangan penelitian tersebut, prosedur eksperimen penelitian terangkum sebagai berikut.

Tabel 3. Prosedur pelaksanaan eksperimen

\begin{tabular}{llll}
\hline $\mathrm{R}$ & $\mathrm{T}_{1}$ & $\mathrm{x}_{1} \mathrm{y}_{1}$ & $\mathrm{~T}_{2}$ \\
$\mathrm{R}$ & $\mathrm{T}_{1}$ & $\mathrm{x}_{1} \mathrm{y}_{2}$ & $\mathrm{~T}_{2}$ \\
$\mathrm{R}$ & $\mathrm{T}_{1}$ & $\mathrm{x}_{2} \mathrm{y}_{1}$ & $\mathrm{~T}_{2}$ \\
$\mathrm{R}$ & $\mathrm{T}_{1}$ & $\mathrm{x}_{2} \mathrm{y}_{2}$ & $\mathrm{~T}_{2}$ \\
\hline
\end{tabular}

Keterangan:

$\mathrm{x}_{1} \mathrm{y}_{1}$ : Kelas MTDKBI-STAD

$\mathrm{x}_{1} \mathrm{y}_{2}$ : Kelas MTDKBI-NHT

$\mathrm{x}_{2} \mathrm{y}_{1}$ : Kelas nonMTDKBI-STAD

$\mathrm{x}_{2} \mathrm{y}_{2}$ : Kelas nonMTDKBI-NHT

$\mathrm{R}$ : random $; \mathrm{T}_{1}$ : nilai pretes; $\mathrm{T}_{2}$ : nilai postes

Populasi penelitian adalah 380 siswa yang tersebar pada 10 kelas SMPN 10 Mataram. Sampel penelitian terdiri dari 142 siswa, terbagi menjadi 4 kelas yang diambil dengan teknik Cluster Random Sampling yaitu pengambilan sampel dengan memperhatikan unsur kelas atau kelompok yang terdapat dalam populasi [20]. Instrumen penelitian berupa angket sikap ilmiah yang sudah divalidasi dan diberikan pada awal dan akhir penelitian.
Analisis data sikap ilmiah siswa menggunakan Anakova dua jalur pada taraf signifikan 0,05. Analisis statistik diawali dengan uji normalitas dengan Kolmogorov-Smirnov dan uji homogenitas menggunakan Levene test. Proses penghitungan dibantu dengan program aplikasi Microsoft Excel versi 2010 dan SPSS versi 18 for Windows.

\section{HaSil dan PEMBaHasan}

Sikap ilmiah siswa yang belajar dengan MTDKBI lebih baik dibandingkan dengan siswa yang belajar dengan nonMTDKBI. Hal ini tercermin dari 9 indikator sikap ilmiah meliputi keingintahuan, kejujuran, keterbukaan, skeptis, objektivitas, kedisiplinan, tanggung jawab, keberanian dalam kebenaran dan ketelitian. Skor siswa yang belajar dengan MTDKBI lebih tinggi 14,97\% pada indikator keingintahuan, $14,66 \%$ pada kejujuran, $11,15 \%$ pada keterbukaan, $20,13 \%$ pada skeptis, $12,93 \%$ pada objektivitas, $16,58 \%$ pada kedisiplinan, $13,86 \%$ pada tanggung jawab, 6,94\% pada keberanian dalam kebenaran, 29,45\% pada berpikir ke depan dan $14,19 \%$ pada ketelitian.

Data pada Tabel 4. menjadi bukti empirik bahwa pengaruh penerapan MTDKBI terhadap sikap ilmiah siswa lebih baik dibandingkan dengan nonMTDKBI. Penggunaan media pembelajaran (MTDK) membantu siswa memahami sifat kemagnetan secara mendalam. Walaupun media yang digunakan sederhana, namun diharapkan dapat membantu siswa memahami magnet lebih baik. Media pembelajaran tidak harus mahal dan canggih, tetapi yang terpenting adalah fungsi dan peranannya dalam meningkatkan proses pembelajaran [4]. Misalnya, melalui percobaan, siswa dapat mengaitkan ukuran dan bentuk magnet yang berbeda terhadap kekuatan gaya tarik magnet, menyelidiki lebih mendalam hubungan jarak suatu magnet terhadap kekuatan gaya tarik magnet. Siswa pun dapat mengaplikasikan dan memanfaatkan magnet dalam beberapa keperluan misalnya pembuatan kompas, generator dan motor listrik sederhana.

Tabel 4. Rerata nilai sikap ilmiah pada setiap model pembelajaran

\begin{tabular}{llll}
\hline $\begin{array}{l}\text { Model } \\
\text { Pembelajaran }\end{array}$ & N & Rerata & Std.Deviasi \\
\hline MTDKBI & 71 & 84,29 & 7,48 \\
Non MTDKBI & 71 & 73,17 & 5,76 \\
STAD & 72 & 79,96 & 9,76 \\
NHT & 70 & 77,47 & 7,27 \\
MTDKBI-STAD & 36 & 87,28 & 7,08 \\
MTDKBI-NHT & 35 & 81,22 & 6,67 \\
\hline
\end{tabular}




\begin{tabular}{lccc}
\hline $\begin{array}{l}\text { Non MTDKBI- } \\
\text { STAD }\end{array}$ & 36 & 72,63 & 5,73 \\
$\begin{array}{l}\text { Non MTDKBI- } \\
\text { NHT }\end{array}$ & 35 & 73,73 & 5,83 \\
\hline
\end{tabular}

Pembelajaran Fisika melalui inkuiri memberikan kesempatan kepada guru untuk mengembangkan kemampuan dan memperkaya siswa tentang Fisika khususnya materi kemagnetan, melalui kegiatan investigasi, menemukan bukti baru, dan menggunakan fakta dari observasi mereka untuk membuat argumen yang beralasan dan ilmiah dalam menjawab pertanyaan yang diajukan. Tentunya hal ini melibatkan berbagai sikap ilmiah antara lain terbuka dengan gagasan baru, berpikir kritis, jujur, kreatif, dan lain-lain [7].

Penerapan pembelajaran dengan MTDKBI melatih siswa untuk melakukan kegiatan pembelajaran melalui langkah-langkah seperti ilmuan menemukan sesuatu yang baru. Melalui LHIKS dan PIKS yang merupakan satu kesatuan dengan MTDKBI, siswa dilatih untuk merumuskan masalah, membuat hipotesis, mengumpulkan, mengolah dan menganalisis data serta membuat kesimpulan. Secara tidak langsung hal ini akan melatih dan menanamkan sikap ilmiah pada siswa yang diperlukan untuk menjadi seorang calon ilmuan (scientist).

Hasil penelitian ini sejalan dengan temuan yang mengungkapkan bahwa ada perbedaan sikap ilmiah antara siswa yang belajar dengan menggunakan perangkat pembelajaran sains berbasis inkuiri (PSBI) dengan siswa yang belajar tanpa menggunakan perangkat PSBI. Siswa yang belajar dengan PSBI memiliki skor yang lebih tinggi $7 \%$ dibandingkan siswa yang belajar dengan nonPSBI [21]. Hasil yang senada juga diperoleh bahwa ada perbedaan sikap ilmiah antara siswa yang belajar dengan perangkat pembelajaran berbasis inkuiri (PPBI) dengan siswa yang belajar dengan perangkat nonPPBI [22].

Penerapan pembelajaran dengan MTDKBI melatih dan menanamkan sikap ilmiah siswa dalam melakukan kegiatan pembelajaran melalui metode ilmiah. Siswa dilatih untuk merumuskan masalah, membuat hipotesis, mengumpulkan, mengolah dan menganalisis data serta membuat kesimpulan.

Tabel 5. Hasil Uji Hipotesis Sikap Ilmiah

\begin{tabular}{lllll}
\hline No & Sumber & Df & $\mathbf{F}_{\mathbf{h}}$ & $\begin{array}{l}\mathbf{P} \\
(\text { sig. })\end{array}$ \\
\hline 1 & Jenis media & $1: 141$ & 96,979 & 0,000 \\
2 & $\begin{array}{l}\text { Strategi } \\
\text { kooperatif }\end{array}$ & $1: 141$ & 14,292 & 0,000 \\
\hline
\end{tabular}

\begin{tabular}{lllll}
\hline 3 & $\begin{array}{l}\text { Jenis } \\
\text { media*strategi }\end{array}$ & $1: 141$ & 17,572 & 0,000 \\
\hline
\end{tabular}

Pada dasarnya, semua indikator sikap ilmiah siswa terbina dengan serangkaian kegiatan eksperimen yang dilakukan mulai dari menyusun rumusan masalah sampai mendiskusikan permasalahan tersebut dengan teman kelompoknya dan menyimpulkan pendapat yang paling relevan sebagai suatu kesimpulan kelompoknya.

Sikap ilmiah siswa dengan strategi kooperatif tipe STAD berbeda secara signifikan dengan tipe NHT (Tabel 5). Siswa yang belajar dengan strategi kooperatif tipe STAD memililki skor sikap ilmiah lebih tinggi 3,2\% dibandingkan dengan siswa yang belajar melalui strategi kooperatif tipe NHT. Siswa yang belajar melalui strategi kooperatif tipe STAD dibandingkan siswa yang belajar dengan tipe NHT berbeda signifikan pada lima (5) dari sepuluh (10) indikator sikap ilmiah siswa yaitu rasa ingin tahu, kejujuran, kedisiplinan, berpikir ke depan dan ketelitian. Walaupun pada semua indikator tidak berbeda signifikan antara siswa yang belajar melalui strategi kooperatif tipe STAD dengan NHT, namun tipe STAD lebih unggul dibandingkan tipe NHT pada semua indikator berdasarkan analisis data secara diskriptif. Skor siswa yang belajar dengan tipe STAD lebih tinggi 3,89\% pada keingintahuan, $1,22 \%$ pada kejujuran, 3,35\% pada keterbukaan, 2,40\% pada skeptis, 2,87\% pada objektivitas, 5,20\% pada kedisiplinan, $1,74 \%$ pada tanggung jawab, 2,67\% pada keberanian dalam kebenaran, 6,04\% pada berpikir ke depan dan 4,65\% pada ketelitian.

Siswa yang belajar dengan strategi kooperatif tipe STAD berbeda signifikan pada 5 indikator sikap ilmiah dibandingkan dengan tipe NHT karena sintaks dari kedua strategi ini berbeda. Tipe STAD lebih unggul pada indikator kejujuran karena siswa dilatih untuk mengerjakan kuis individu dengan jujur. Kalau diketahui tidak jujur akan merugikan kelompoknya karena skor kelompok mereka dikurangi sehingga harapan untuk menjadi kelompok terbaik sulit terealisasi. Beda halnya dengan siswa yang belajar dengan tipe NHT, hanya ditekankan pada aspek tanggung jawab untuk menjadi tim terbaik. Penskoran kelompok didasarkan jawaban seorang anggota sebagai wakil jawaban kelompoknya. Siswa yang belajar dengan tipe STAD memperoleh skor ketelitian dan kedisiplin yang lebih baik dibandingkan tipe NHT karena setiap individu diasah ketika menjawab kuis dengan benar, teliti dan tepat waktu saat menjawab kuis, sedangkan pada tipe NHT hanya satu individu yang menjadi anggota kelompok saja yang terbina untuk memberi jawaban dengan benar dan tepat waktu sebagai wakil jawaban kelompok. 
Interaksi antara MTDKBI dengan strategi kooperatif berpengaruh terhadap sikap ilmiah siswa (Tabel 5). Hal ini membuktikan MTDKBI memberikan hasil yang lebih baik jika diintegrasikan dengan strategi kooperatif dalam meningkatkan sikap ilmiah siswa. Berdasarkan uji lanjut, pembelajaran dengan menggunakan MTDKBI yang diintegrasikan dengan strategi kooperatif tipe STAD lebih baik jika dibandingkan pembelajaran MTDKBI-NHT, begitu pula jika MTDKBI-STAD dan MTDKBI-NHT dibandingkan dengan nonMTDKBI-NHT dan nonMTDKBI-STAD. Pembelajaran dengan menggunakan MTDKBI yang diintegrasikan dengan strategi kooperatif tipe STAD memperoleh skor ratarata sikap ilmiah lebih tinggi $7,46 \%$ jika dibandingkan dengan penggunaan MTDKBI yang dintegrasikan dengan strategi kooperatif tipe NHT, $18,38 \%$ dibandingkan dengan nonMTDKBI-NHT dan 20,17\% dibandingkan nonMTDKBI-STAD.

Implementasi MTDKBI yang dipadukan dengan strategi kooperatif menjadi salah satu jawaban dari persoalan yang terjadi selama ini dalam memompa sikap ilmiah siswa agar menjadi lebih baik. Sikap ilmiah harus menjadi bekal bagi setiap siswa sebelum merespon sesuatu baik dalam bentuk ucapan maupun tindakan. Sikap ilmiah yang ditanamkan melalui pembelajaran dengan MTDKBI yang disinergikan dengan strategi kooperatif akan melatih pembentukan karakter siswa yang termuat dalam indikator sikap ilmiah yaitu keingintahuan, kejujuran, keterbukaan, skeptis, objektivitas, kedisiplinan, tanggung jawab, keberanian dalam kebenaran, berpikir ke depan dan ketelitian. Pembelajaran kooperatif tidak hanya mencakup beragam tujuan sosial, tetapi juga dimaksudkan untuk meningkatkan kinerja siswa dalam tugas-tugas akademik yang penting. Pemberian reward (penghargaan) kepada siswa pada pembelajaran dapat memicu semangat siswa untuk berprestasi [12].

Siswa-siswa pada kelas MTDKBI-STAD dan MTDKBI-NHT dilatih rasa ingin tahu dan berpikir ke depan dengan membuat rumusan masalah dan hipotesis dalam LHIKS. Kejujuran mereka diasah dengan melaksanakan eksperimen sesuai dengan prosedur yang ada pada PIKS, mengerjakan kuis dan menjawab pertanyaan oleh guru tanpa membuat kecurangan dengan menyontek maupun bertanya pada temannya. Kedisiplinan, mereka diajarkan agar dalam mengerjakan eksperimen diusahakan tepat waktu. Ketelitian mereka ditempa dengan melaksanakan percobaan seteliti mungkin sebelum data yang diperoleh diolah kemudian mengulangi lagi percobaan yang mereka lakukan. Skeptis mereka dilatih dengan tidak langsung percaya terhadap asumsi atau hipotesis yang mereka bangun namun harus dibuktikan terlebih dahulu melalui percobaan, mengumpulkan, dan menganalis data serta memverifikasikan dengan literatur (Buku Saku Kemagnetan Siswa). Keberanian dalam kebenaran dan objektivitas mereka dilatih ketika menulis data hasil penelitian sesuai dengan eksperimen walaupun berbeda dari hipotesis dan literatur yang ada. Pada dasarnya, semua indikator sikap ilmiah siswa terbina dengan serangkaian kegiatan eksperimen yang dilakukan mulai dari menyusun rumusan masalah sampai mendiskusikan permasalahan tersebut dengan teman kelompoknya dan menyimpulkan pendapat yang paling relevan sebagai suatu kesimpulan kelompoknya.

\section{PenutuP}

Kesimpulan berdasarkan hasil penelitian yaitu: (1) Sikap ilmiah siswa yang belajar menggunakan MTDKBI berbeda signifikan dengan nonMTDKBI, (2) Sikap ilmiah siswa yang belajar melalui strategi kooperatif tipe STAD berbeda signifikan dengan tipe NHT, (3) Ada pengaruh interaksi antara MTDKBI dengan strategi kooperatif terhadap sikap ilmiah siswa.

Pembelajaran Fisika sebaiknya menggunakan media dalam hal ini MTDKBI yang disinergikan dengan strategi kooperatif agar dapat membina sikap ilmiah siswa.

\section{REFERENSI}

[1] Handayanto, S. K. 2003. Strategi Pembelajaran Fisika. Malang: UNM.

[2] Wena, M. 2009. Strategi Pembelajaran Inovatif Kontemporer Suatu Tinjauan Konseptual Operasional. Bumi Aksara: Jakarta.

[3] Muhson, A. 2010. Pengembangan Media Pembelajaran Berbasis Teknologi Informasi. Jurnal Pendidikan Akutansi Indonesia VIII (2): 1-10.

[4] Sudjana, N. \& Rivai, A. 2011. Media Pengajaran. Bandung: Sinar Baru.

[5] Daryanto. 2010. Media Pembelajaran. Yogyakarta: Grava Media.

[6] Bass, J. E., Contant, T. L. dan Carin, A. A. 2009. Teaching Science as Inquiry. Boston: Pearson Inc.

[7] Muchtar, Z. \& Arsidah P. 2009. Penerapan Metode Inquiry Berbasis Kelas dalam Pembelajaran Struktur Atom. Jurnal Pendidikan Matematika dan Sains 4: 35-40.

[8] Hamalik, O. 2011. Proses Belajar Mengajar. Jakarta: Bumi Aksara.

[9] Jufri, A. W. 2008. Implementasi Pembelajaran Berbasis Inkuiri, Tantangan dan Harapan Bagi 
Guru Pelajaran Sains. Prosiding Seminar Nasional PMIPA FKIP UNRAM "Pengembangan Profesionalisme Pendidik Menghadapi Tantangan Pembelajaran Matematika dan Sains". Mataram: Universitas Mataram.

[10] Gulo, W. 2008. Strategi Belajar Mengajar. Jakarta: Grasindo.

[11] Rusman. 2010. Model-Model Pembelajaran Mengembangkan Profesionalisme Guru. Jakarta: Rajawali Press.

[12] Arends, R. I. 2008. Learning to Teach (Belajar untuk Mengajar) Edisi Ketujuh. Helly, P. S. \& Sri, M. S. (Penerjemah). Yogyakarta: Pustaka Belajar.

[13] Ibrahim, M., Rachmadiati, F., Nur, M. \& Ismono. 2000. Pembelajaran Kooperatif. Pusat Sains dan Matematika Sekolah. Program Pascasarjana UNESA. Surabaya: University Press.

[14] Slavin, R. E. 2011. Psikologi Pendidikan Teori dan Praktik Jilid II Edisi Kesembilan. Penerjemah Marianto Samosir. Jakarta: Indeks.

[15] Puskur. 2007. Naskah Akdemik Kajian Kebijakan Kurikulum Mata Pelajaran IPA. Jakarta: Pusat Kurikulum, Balitbang Depdiknas.

[16] Wahyudiati, D. 2010. Pengembangan Perangkat Pembelajaran Berorientasi Model Pembelajaran Diskusi pada Pokok Bahasan Energi dan Perubahannya untuk Menumbuhkan Sikap Ilmiah Siswa. Jurnal Inovasi dan Pendidikan 3 (1): 363.

[17] Hassard, J. \& Dias, M. 2009. The Art of Teaching Science. London: Oxford University Press.

[18] BSNP. 2006. Standar Isi untuk Satuan Pendidikan Dasar dan Menengah: SK dan KD SMP/MTs. Jakarta: BSNP.

[19] Arifin, E. Z. 2008. Dasar-Dasar Penulisan Karya Ilmiah Lengkap dengan Kaidah Bahasa Indonesia yang Benar untuk Perguruan Tinggi. Jakarta: Grasindo.

[20] Furchan, A. 1982. Pengantar Penelitian dalam Pendidikan. Surabaya: Usaha Nasional.

[21] Sukiman, M. S. 2010. Efektivitas Penerapan Model Pembelajaran Sains Berbasis Inkuiri melalui Strategi Kooperatif terhadap Perkembangan Sikap Ilmiah dan Minat serta Hasil Belajar Biologi Siswa SMPN 2 Mataram. Tesis S2. Universitas Mataram.

[22] Jufri, A. W. 2009. Implementation of The Inquiry Based Learning Kit Trough Cooperative Learning Strategy to Develop Attitudes of SMA Student in Mataram. Proceedings The $3^{\text {rd }}$ International
Seminar on Science Education "Challenging Science Education in The Digital Era". Bandung: Universitas Pendidikan Indonesia.

\section{Biografi Penulis}

Dr. Ahmad Harjono, S.Si., M.Pd., Lahir di Lamongan, 23 Nopember 1967. Alamat rumah di Jl. Gunung Kerinci 48 Mataram. Penulis telah menyelesaikan S-1 pada Prodi Fisika FMIPA Universitas Brawijaya Malang, S-2 Prodi Magister Pendidikan Sains PPs Universitas Surabaya dan S-3 Prodi Teknologi Pendidikan di Universitas Malang. Penulis menjadi Dosen di Lingkungan Universitas Mataram semenjak tahun 1994 di Prodi Pendidikan Fisika, PGSD, dan S-2 Pendidikan IPA. Sekarang menjabat sebagai Kaprodi Pendidikan Fisika Universitas Mataram. Banyak penelitian dan artikel yang telah ditelurkan di jurnal-jurnal ilmiah oleh penulis, termasuk buku bahan ajar, diktat dan modul. Matakuliah yang diampu antara lain metodologi penelitian, fisika modern, mekanika.

Prof. Dr. Abdul Wahab Jufri, M.Sc. Lahir di Baturotok, Sumbawa pada tanggal 25 Desember 1962. Sekarang tinggal di Jln. Kesejahteraan Raya No. 64 Mataram, NTB, Telp. (0370) 623873. Penulis telah menyelesaikan S1 di Prodi Pendidikan Biologi FKIP Universitas Mataram, kemudian melanjutkan S2 pada bidang Natural Resources di Curtin University, Pearth Australia. Setelah itu merampungkan S3 di Prodi Pendidikan Biologi PPs Universitas Malang. Penulis sudah meraih gelar guru besar (profesor) dalam bidang pendidikan biologi. Penulis pun berusaha mengemban amanah Tri Dharma perguruan tinggi dengan aktif melaksanakan penelitian dan pengabdian pada masyarakat serta mempublikasikan hasil-hasil karya melalui seminar, konfrensi, dan jurnal ilmiah. Fokus penelitian dan karya ilmiah penulis pada upaya perbaikan kualitas pendidikan bidang IPA di sekolah menengah maupun perguruan tinggi. Dalam melaksanakan tugas sebagai abdi negara penulis selalu teguh memegang prinsip "Berjuang untuk menggapai hidup yang lebih baik, berkarya untuk memberi manfaat kepada orang lain, dan bekerja dengan ikhlas untuk meraih ridha Allah SWT". Jenjang karir yang penulis lalui di antaranya sebagai Staf Pengajar (Dosen) pada Jurusan Pendidikan MIPA, Program Studi Pendidikan Biologi, FKIP, Universitas Mataram (1987 sekarang). Beliau juga aktif sampai sekarang mengisi kuliah di Prodi Magister Pendidikan IPA dan Prodi Magister Administrasi Pendidikan di PPs Unram. Penulis juga pernah menjabat sebagai Ketua Jurusan 
PMIPA FKIP Unram tahun 2009 - 2012 dan Ketua Tim Penyusun Kode Etik Pelaku Penelitian di Universitas Mataram, tahun 2014.

Kurniawan Arizona, S.Si, M.Pd., Lahir di Sakra, Lombok Timur pada tanggal 16 April 1987. Sekarang tinggal di Lingkungan Karang Baru Selatan, Kelurahan Karang Baru Kecamatan Selaparang Mataram. Penulis telah menyelesaikan S1 pada Prodi
Fisika FMIPA Universitas Brawijaya Malang dan S2 Prodi Magister Pendidikan IPA PPs Universitas Mataram. Sekarang menjadi Staf Pengajar Prodi Pendidikan Fisika Universitas untuk Matakuliah Elektronika Dasar I \& II dan Metodologi Penelitian (Januari 2014-sekarang). Artikel ilmiah yang pernah dipublikasi pada Jurnal Erudio Universitas Brawijaya Volume I Edisi I bulan Juni. 